\title{
Da narrativa na arte: espaço-tempo figurativo e istoria na pintura pós-medieval ${ }^{1}$
}

\author{
Fernando António Baptista Pereira \\ Universidade de Lisboa
}

\section{Resumo}

Neste texto vamos procurar discernir algumas das transformações na organização narrativa das imagens pictóricas face às grandes categorias do espaço-tempo figurativo que se sucederam nos séculos XV, XVI e XVII. Antes, porém, abordaremos os fundamentos teóricos dos estudos da narrativa visual e passaremos em revista os modelos de narrativa visual que, desde a mais remota Antiguidade ao Renascimento, pela Idade Média, se foram sucedendo em distintos suportes e meios, acabando por se concretizar em diferentes padrões de composição retabular e de organização narrativa. Trataremos, também, algumas das principais estratégias de construção da imagem, no dealbar do «espaço teatral renascentista», progressivamente dominado pelas leis da perspetiva e aberto a novas modalidades de narratividade, procurando compreender a passagem de uma imagem de devoção predominantemente «icónica» (dominada por uma «moda» de nobilitas que atravessou a produção do terceiro quartel de quatrocentos, da Itália à Flandres) aos grandes conjuntos «narrativos».

\section{Abstract}

In this text we shall attempt to define some of the transformations in the narrative organization of pictorial images when faced with the major successive categories of figurative space-time from the $15^{\text {th }}, 16^{\text {th }}$ and $17^{\text {th }}$ centuries. Before that, however, we shall approach the theoretical foundations of visual narrative studies and review the visual narrative models that, from the remotest Antiquity to the Middle Ages and the Renais-

$\infty<\infty<\infty<\infty<\infty \times \infty \times \infty \times \infty \times \infty \times \infty \times \infty$

1 Este texto retoma e desenvolve alguns dos capítulos iniciais da nossa dissertação de doutoramento intitulada Imagens e Histórias de Devoção. Espaço Tempo e Narrativa na Pintura Portuguesa do Renascimento (1450-1550), Lisboa: Faculdade de Belas Artes da Universidade de Lisboa, 2001. Foi apresentado, em 2003, como comunicação ao Colóquio Internacional Estética e Artes. Controvérsias para o século XXI, Lisboa, Faculdade de Letras da Universidade de Lisboa, 2003, e publicado nas respetivas Atas: Isabel Matos Dias et al., Estética e Artes. Controvérsias para o século XXI, Lisboa: Centro de Filosofia da FLUL, 2005, pp. $277-301$. Republicamo-lo com atualizações e acrescentos. 
sance, evolved in different supports and means, eventually consubstantiating themselves in different patterns of altarpiece composition and narrative organization. We will also deal with some of the main strategies for image making, in the dawn of the "Renaissance theatrical space", progressively dominated by the rules of perspective and open to new modes of narrativity, seeking to understand the evolution of a predominantly "iconic" image of devotion (influenced by a "fashionable" nobilitas that spanned the production of the third quarter of the $15^{\text {th }}$ century) to the large "narrative" ensembles.

O quadro renascentista é uma janela aberta para o imaginário. Foi o grande teórico do quattrocento Leon Battista Alberti ${ }^{2}$ que o disse, no seu tratado De Pictura (1435): «Em primeiro lugar, inscrevo na superfície a pintar um rectângulo do tamanho que me aprouver, feito de ângulos rectos, e que é para mim como uma janela aberta, através da qual observo a istoria, e aí determino o tamanho que quero dar aos homens na minha pintura» ${ }^{3}$. Nesta frase central do tratado de Alberti, que nem sempre tem sido compreendida em todas as suas implicações ${ }^{4}$, para além de uma súmula da construção técnica da própria perspetiva ${ }^{5}$ e da constituição do que Jean-Louis Déotte chama o «aparelho

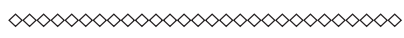

2 Sobre a personalidade multifacetada e a obra de Alberti ver o catálogo da exposição dedicada ao arquitecto, humanista e teórico da arte, AA. VV. Leon Battista Alberti, Mântua: Olivetti/Electa, 1994.

3 Alberti, De La Peinture / De Pictura (1435), ed. do texto latino e trad. franc. de Jean Louis Schefer, com prefácio de Sylvie Deswarte-Rosa, Paris: Dédale, 1993, Livro I, pp. 114-115. Versão portuguesa nossa. Na tradução portuguesa da obra de Erwin Panofsky, Renascimento e Renascimentos na Arte Ocidental, Lisboa: Presença, 1981, p. 169, vem publicada a seguinte versão, que, noutra ocasião, chegámos a utilizar: «descrevo um rectângulo do tamanho que me aprouver e imagino-o como uma janela aberta através da qual observo o que quer que deva ser ali representado». Esta versão do texto baseia-se na tradução inglesa de John R. Spencer feita a partir da versão italiana da obra, Della pittura, realizada pelo próprio Alberti no ano imediato ao do original latino (cf. John R. Spencer (tradução, introdução e notas), Leon Battista Alberti. On Painting, New Haven: Yale Univ. Press, 1966, p. 56). Apesar de Spencer dar, em nota, a versão latina, a omissão do conceito de istoria nessa versão «em língua vulgar» reduz substancialmente o alcance do texto original latino.

4 John R. Spencer, op. cit., p. 13, critica, com razão, aqueles que, até então, haviam «lido» o conceito albertiano de istoria a partir da teoria «académica» do século XVII, restringindo-o ao género de "pintura de história» (sagrada ou mitológica) ou à pintura narrativa, mas não há dúvidas, como nota, com pertinência, Jean Louis Scheffer, que «o programa "realista" de Alberti [e de quase todo o quattrocento, acrescentamos nós] exige que a pintura mostre e narre» (op. e loc cit., nota 1). Ainda sobre Alberti e o conceito de istoria, ver o estudo de Alain Laframboise, Istoria et Théorie de l'Art. Italie, XVe et XVIe siècles, Montréal: PUM, 1989, especialmente pp. 47-99.

5 Cf. Kim Veltman, Military Surveying and topography: the practical dimension of Renaissace Linear Perspective, Lisboa: Centro de Estudos de Cartografia Antiga, 1979, pp. 12-27, que enumera, ainda, como instrumentos auxiliares da perspectiva, o «método dos cordéis» de Piero della Francesca, com as suas variantes, o «radius» ou «baculus» de Jacob, também com as suas variantes, além de outros instrumentos, como o quadrante e o astrolábio. 
perspetivo ${ }^{6}$, deparamos com a introdução de um outro conceito fulcral do Tratado e, aliás, de todo o Renascimento, o de istoria, em si uma noção profundamente carregada de dimensão narrativa ${ }^{7}$.

Neste texto vamos procurar discernir algumas das transformações na organização narrativa das imagens pictóricas face às grandes categorias do espaço-tempo figurativo ${ }^{8}$ que se sucederam nos séculos XV, XVI e XVII. Antes, porém, passaremos em revista os modelos de narratividade visual que, desde a mais remota Antiguidade ao Renascimento, pela Idade Média, se foram sucedendo em distintos suportes e meios, acabando por se concretizar em diferentes padrões de composição retabular e de organização narrativa. Abordaremos, também, algumas das principais estratégias de construção da imagem, no dealbar do «espaço teatral renascentista», progressivamente dominado pelas leis da perspetiva e aberto a novas modalidades de narratividade, procurando compreender a passagem de uma imagem de devoção predominantemente «icónica» (dominada por uma «moda» de nobilitas que atravessou a produção do terceiro quartel de quatrocentos, da Itália à Flandres) aos grandes conjuntos «narrativos».

\section{Para uma história da narração por imagens}

A nossa abordagem da pintura pós-medieval privilegia as modalidades de narratividade que podemos identificar tanto ao nível da composição isolada como ao nível das séries de composições. Trata-se de um modelo teórico que nasceu não só da iconologia de Aby Warburg e de Erwin Panofsky ${ }^{9}$ mas da influência exercida pelos estudos de

$\infty<\infty<\infty<\infty<\infty<\infty<\infty<\infty<\infty<\infty<\infty$

6 Cf. Jean-Louis Déotte, Lépoque de l'appareil perspectif (Brunelleschi, Machiavel, Descartes), Paris: L'Harmattan, 2001, especialmente pp. 15-26.

7 Cf. Idem, ibidem, pp. 142-151.

8 Ver, de Pierre Francastel, as definições de espaço-tempo figurativo, de realidade figurativa e de imaginário nos seus textos fundamentais: Études de Sociologie de l'Art, Paris: Denoël-Gonthier, 1970, que retoma os ensaios publicados em Peinture et Société. Naissance et destruction d'un espace plastique, de la Renaissace au Cubisme, Paris-Lyon: Audin, 1951, La Réalité Figurative, Paris, Gonthier, 1965, que recolhe os estudos em que desenvolve os princípios teóricos da sua abordagem «sociológica», e, finalmente, a mais completa aplicação desses princípios, La figure et le Lieu. Lordre visuel du Quattrocento, Paris: Gallimard, 1967.

9 Ver, de Erwin Panofsky, «Introdução» in Estudos de Iconologia, Lisboa: Estampa, 1995, pp. 19-40. A primeira edição do original em inglês é de 1939. Ao definir a iconologia, o autor fala num «método de interpretação que surge mais como síntese do que como análise» (p. 23). Em 1955, ao republicar o texto na colectânea O Significado nas Artes Visuais (Lisboa: Presença, 1989, pp. 33-35), Panofsky desenvolveu muito esta ideia, acrescentando alguns parágrafos ao texto original, em que contrapõe ao carácter descritivo da iconografia, no sentido corrente do termo, o carácter interpretativo da iconologia para estabelecer a sequência de leitura da obra de arte que se tornou clássica entre os iconólogos - descrição pré-iconográfica dos motivos, análise iconográfica e interpretação iconológica - à qual há que aplicar princípios de correcção científica (a «história dos estilos» no primeiro caso, a «história dos tipos», no segundo, e a «história dos sintomas culturais ou símbolos» no terceiro). Sobre as relações da iconologia com a semiótica da arte ver Omar 
semiótica sobre a história da arte, numa perspectiva verdadeiramente transdisciplinar, cruzando metodologias que vão da teoria literária à antropologia, passando pela história social, abordagem que tem em Norman Bryson um dos expoentes máximos.

Este historiador, num texto publicado em $1991^{10}$, que sintetizava o programa teórico que aplicara alguns anos antes em Vision and Painting. The Logic of the Gaze ${ }^{11}$, exerceu uma pertinente crítica do modelo «perceptualista» do historiador E. H. Gombrich, austríaco naturalizado inglês, diretor durante largos anos do prestigioso Warburg Institute de Londres, uma das «casas-mãe» da iconologia, que realizou uma frutuosa síntese entre o gestaltismo e o método iconológico na sua leitura do modus faciendi da imagem (ou, utilizando a expressão na língua original, o image-making) ${ }^{12}$. Segundo Norman Bryson, o método «perceptualista» de Gombrich implica uma leitura do «fazer» da imagem que explora preferencialmente o arco da chamada "visão interior», individual, que vai "do pincel à retina», enquanto o modelo semiológico, que reconhece a pintura como signo ou discurso, ou seja, como «um arco que se estende de pessoa a pessoa e através de um espaço inter-individual», pressupõe a compreensão «dos códigos de reconhecimento que são aprendidos com os outros, na aquisição da cultura humana ${ }^{13}$. Bryson insiste, assim, na ideia de que a pintura, como actividade sígnica, se desenvolve no interior da formação social desde o início, negando a ideia de que a sociedade se apropriaria ou utilizaria a imagem apenas depois de ela ser gerada, uma vez que «a formação social está inerente e imanentemente presente na imagem» ${ }^{14}$.

A crítica que Bryson dirige à visão da produção de imagens excessivamente centrada no indivíduo (na ocorrência, o «artista»), segundo o modelo teórico que designa por «perceptualismo», estende-se também aos modelos «reducionistas» e simplisticamente «economicistas» do Materialismo Histórico, que relegam a expressão artística a um «efeito» super-estrutural do modo de produção, determinante na formação social, uma vez que o autor considera, muito acertadamente, que a teia de relações múltiplas que se estabelece entre o produtor de imagens e a sociedade é atravessada pela «corrente

Calabrese, A Linguagem da Arte, Lisboa: Presença, 1986, pp. 24-34, com numerosa bibliografia actualizada. 10 Norman Bryson, «Semiology and Visual Interpretation» in Norman Bryson, Michael Ann Holly e Keith Moxey (eds.) Visual Theory, Cambridge: Polity Press, 1991, pp. 61-73.

11 Citamos a trad. cast., Norman Bryson, Visión y Pintura La Lógica de la mirada, Madrid: Alianza, 1991.

12 Cf. Norman Bryson, «Semiology and Visual Interpretation» in Bryson, Holly e Moxey (eds.) Visual Theory, cit., p. 65.

13 Idem, ibidem, pp. 65-66.

14 Cf. Norman Bryson, «Semiology and Visual Interpretation», cit., p. 66. Neste ponto, Bryson reencontra a noção francasteliana da arte como «facto social», consignada na célebre fórmula que define a obra de arte: «o criador encarnando a sensibilidade comum do seu tempo - e o observador que recebe e interpreta a mensagem», citada por José-Augusto França no Prefácio ao primeiro livro de Pierre Francastel traduzido em português - Arte e Técnica, Lisboa: Livros do Brasil, s. d. [1963], p. 11. As concepções de Francastel viriam a ser consideradas precursoras da abordagem semiológica da arte. Ver, sobre este assunto, AA. VV. La Sociologie de l'Art et sa vocation interdisciplinaire. Francastel et après, Paris: Denoel-Gonthier, 1976. 
de signos», ou seja, por aquilo que designa de «poder discursivo» ${ }^{15}$. Ora, esta instância, transversal a toda a formação social, comporta um carácter por assim dizer bi-direccional, pois, se é verdade que a pintura se alimenta dos códigos sociais de reconhecimento, também não é menos verdade que o seu «trabalho significante» sobre esses códigos os devolve à sociedade "como frescas e renovadas correntes de discurso» ${ }^{16}$. Daí o seu tão especial «poder», poder que «pode ser visto em cada acto do olhar, em que a forma discursiva da imagem encontra os discursos transportados sobre a imagem pelo espectador e produz uma mudança, ou em que, para reconhecer a forma discursiva da imagem, têm de ser modificados e subvertidos tanto as fronteiras existentes do discurso como as categorias e os códigos de reconhecimento, para que a imagem possa ser reconhecida ${ }^{17}$.

Esta renovada abordagem semiológica da pintura - e, por extensão, da arte - confere, segundo Bryson, uma dupla tarefa ao historiador: por um lado, uma atitude que designa de «arquival» (não puramente arquivística, claro), ou seja, situar a pintura no seu contexto de origem, não apenas no que toca a patrocínio ou encomenda, mas também no que se refere a todos os outros aspectos de uma complexa interacção com todas as práticas da esfera da cultura, do universo científico, médico, intelectual ou religioso até à estrutura de classes, à vivência da sexualidade e à economia ${ }^{18}$; por outro, aceitar o carácter "projetivo» do signo, que confere à história da arte não apenas a tarefa de reconstituição do contexto original, mas também a da restituição das continuadas interpretações exercidas sobre a obra de arte ou das funções que lhe são atribuídas ao longo do seu período de vida na sociedade e na cultura, independentemente do contexto que lhe deu origem, e tendo em conta que o «então» de qualquer obra de arte só se «revela» no «agora» da sua leitura ${ }^{19}$.

$\infty<\infty<\infty<\infty<\infty<\infty<\infty<\infty<\infty<\infty<\infty<$

15 Cf. Norman Bryson, «Semiology and Visual Interpretation», cit., pp. 68-69.

16 Idem, ibidem, p. 70.

17 Idem, ibidem, p. 71. No texto original, dá-se como exemplo da dificuldade de «reconhecimento da forma discursiva da imagem», pelas categorias e códigos dominantes, a recepção ao famoso quadro Olympia, de Édouard Manet, quando foi apresentado no Salon de Paris, em 1865. Sobre esta notável pintura e a sua original estratégia conceptual, ver Fernando António Baptista Pereira «A Olympia de Manet à luz dos Untitled Film Stills de Cindy Sherman» in J. Quaresma e F. Rosa Dias (eds.) Investigação em Arte. Uma floresta, muitos caminhos, Lisboa: CIEBA-FBAUL, 2010, pp. 205-219.

18 N. Bryson, «Semiology and Visual Interpretation», cit., p. 72. Neste ponto Bryson recupera, de algum modo, o projecto metodológico abrangente da iconologia panofskyana, enriquecendo-o com o recurso a um conceito antropológico de cultura, que notoria e vantajosamente diferencia a «semiótica» da arte que propõe das leituras semiológicas derivadas do estruturalismo francês (exemplificadas na obra de Jean-Louis Scheffer, Scénographie d’un tableau, Paris: Seuil, 1969).

19 N. Bryson, «Semiology and Visual Interpretation», cit., pp. 72-73. É inegável a influência que sobre o historiador acaba por exercer o debate contemporâneo sobre a arte, quanto mais não seja no desencadear de interrogações suscitadas pelo presente em leituras de obras do passado. É necessário, todavia, notar que Bryson recusa a «anarquia» interpretativa que poderia derivar da consciência da profunda historicidade do acto interpretativo, considerando no âmbito do puro pragmatismo tanto a separação como a dissolução da fronteira entre o «significado original» e a «interpretação subsequente». 
$\mathrm{Na}$ sequência desta proposta de novos modelos de interpretação semiológica da pintura, levada a cabo pelo conjunto da obra de Norman Bryson, com vista não propriamente ao estabelecimento de (mais) uma «teoria da interpretação» mas a uma renovação pragmática das práticas de leitura da obra de arte, fortemente influenciada, é certo, pela teoria literária ${ }^{20}$ mas também pela antropologia e pela história cultural, desenvolveu-se, nos países anglo-saxónicos, uma «nova» historiografia artística que se propôs explorar territórios de confluência entre temáticas antropológicas e sociológicas, como o corpo, a sexualidade ou a imagem da mulher ${ }^{21}$, assim como cruzamentos entre diversos tipos de expressão, nomeadamente entre a expressão literária e a expressão pictural. Um dos «lugares notáveis» dessa nova historiografia foram os estudos sobre o espaço, o tempo e a narratividade.

Com efeito, desde os anos oitenta do século XX que se têm sucedido na historiografia dos países anglo-saxónicos os estudos sobre a narratividade visual, que nos permitem delinear uma verdadeira história da narração por imagens, desde a Antiguidade Egípcia ao Renascimento, que iremos, de seguida, resumir mediante exemplos paradigmáticos. É na colecção intitulada Cambridge Studies in New Art History and Criticism, dirigida pelo próprio Norman Bryson, que tem sido apresentado à comunidade científica internacional o principal esforço renovador dessa «nova» história da arte anglo-americana, em variadas abordagens interdisciplinares ou especificamente relacionadas com a teoria literária, a antropologia e a história da cultura, procurando demonstrar a infinita capacidade de extensão verbal da imagem, obrigando o espectador a tomar parte activa e um papel criativo no diálogo com a obra de arte e, sempre que possível, no caso da narratividade visual, revelando o narrador ao leitor ou observador ${ }^{22}$.

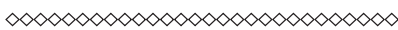

20 Ver o comentário de Stephen Melville ao texto de Bryson, «Reflection on Bryson» in Bryson, Holly e Moxey, Visual Theory, cit., pp. 74-78, assim como o brilhante conjunto de ensaios de Norman Bryson sobre o género Natureza Morta, desde os tempos romanos ao Cubismo, reunidos em Looking at the Overlooked, Londres: Reaktion Books, 1990, em que o autor procura compreender o modo como uma cultura «básica» da rotina doméstica e da hospitalidade foi sobrevivendo historicamente às mudanças sociais e sendo apropriada sucessivamente pelos discursos mais «eruditos» das culturas dominantes.

21 Sobre a problemática do «feminino» na Arte e a vasta bibliografia dos estudos de género, ver o nosso estudo, publicado no último número da Cartema, «Arte e Género. Pinturas de cappriccioso ingegno de Sofonisba Anguissola e Lavinia Fontana», Cartema, Revista do Programa de Pós-Graduação em Artes Visuais UFPE-UFPB, n², Ano I, Recife, Junho de 2013, pp. 9-24.

22 Cf. Peter J. Holliday, «Introduction» in Peter J. Holliday (ed.) Narrative and Event in Ancient Art, Cambridge: Cambridge University Press, 1993, pp. 3-13. O autor traça uma breve história dos estudos sobre a narratividade na arte da Antiguidade, desde os pioneiros colóquios de 1955 (textos publicados em AA. VV. Narration in Ancien Art in American Journal of Archaeology, 1957) até às recentes revisões teóricas da problemática (Pictorial Narrative in Antiquity and the Middle Ages, National Gallery of Art Studies in the History of Art, $n^{\circ} 16$, Washington, 1985), com base na abordagem semiológica inaugurada na história da arte não só por Bryson, mas também, em França, por Louis Marin, com referência a textos do autor sobre a narrativa em Poussin publicados desde 1979. Contudo, para o caso que nos interessa neste trabalho, são muito mais úteis os ensaios de Marin sobre a pintura do quattrocento reunidos em Opacité de la Peinture. Essais sur la représentation au Quattrocento, Paris: Usher, 1989, especialmente o que dedicou a «Piero della Francesca à Arezzo» (pp. 101-124). 
Numa das mais felizes abordagens das mais antigas formas de narratividade visual, Withney Davis procurou «ler» a mensagem do narrador na célebre Paleta de Narmer (Egipto, $1^{\text {a }}$ Dinastia, cerca de 3000 a.C. $)^{23}$. Principiando por inseri-la no contexto produtivo, funcional e cronológico das paletas decoradas de carácter possivelmente votivo, embora não esteja até à data arqueologicamente demonstrada a sua primitiva função, Davis decifrou não só a organização pictural dos elementos entre si no espaço plástico mas, sobretudo, a sequência da sua disposição como episódios que vão «contando»a fábula, num objecto que até então era entendido, pela maioria dos autores, como não-narrativo e meramente simbólico ou alegórico ${ }^{24}$. São fundamentalmente quatro os episódios, que nos obrigam a «ler» a sequência da história desde o que consideraríamos ser o «fim» do campo visual, ou seja a parte inferior da paleta - que é o «antes» da vitória - para o que chamaríamos de "princípio», o topo da paleta - que representa a consumação da mesma, para o que se torna necessário um contínuo movimento de rotação do objecto: 1) o Inimigo resiste e foge ao Rei ou Faraó (no reverso, em baixo); 2) o Rei ou Faraó persegue e conquista o Inimigo (no anverso, em baixo); 3) o Inimigo é apresentado ao Rei ou Faraó (no reverso, em cima); 4) o Rei ou Faraó celebra a morte do Inimigo (no anverso, em cima) ${ }^{25}$.

Os registos centrais - sempre presentes no desenrolar da «fábula», à medida que rodamos a paleta para ler os registos superiores e inferiores e a sequência da «história» - celebram o culminar da vitória, quer com a presença de dois servidores que seguram dois animais de pescoços serpentiformes entrelaçados, que sugerem a própria rotação da paleta, quer com a figuração do clímax, ou seja, a decapitação do chefe inimigo pela figura do Rei ou Faraó, aqui representado em pessoa, numa escala maior do que de todas as restantes figuras ${ }^{26}$. Noutros registos, o Rei é metaforizado pelo touro que irrompe pelas muralhas (segundo episódio) ou associado ao Falcão (seu protector), que apresenta o inimigo pronto para a execução (terceiro episódio). Toda esta organização narrativa denota não apenas um código de valorização da topografia do campo visual que revela os modos de simbolização do espaço na cultura em presença, bem como uma subtil alternância de registos intertextuais que vão da imagem pictórica a algo próximo da escrita ideográfica, passando por zonas de clara presença «hieroglífica» ${ }^{27}$.

Saltando dos primórdios do Egipto Faraónico, em que ainda ecoam os modelos de narratividade de origem pré-histórica, para um outro momento alto de produção de narrativas visuais, a Roma Antiga, coube a Richard Brilliant realizar uma revisão da

$\infty<\infty<\infty<\infty<\infty<\infty<\infty<\infty<\infty<\infty<\infty<$

23 Withney Davis, «Narrativity and the Narmer Palette» in in Peter J. Holliday (ed.) Narrative and Event in Ancient Art, Cambridge: Cambridge University Press, 1993, pp. 14-54.

24 Idem, ibidem, p. 31.

25 Idem, ibidem, pp. 34-38.

26 Idem, ibidem.

27 Idem, ibidem, p. 39. 
importantíssima tradição narrativa presente na arte produzida em solo itálico, desde os Etruscos até ao Império ${ }^{28}$.

A investigação deste historiador partiu da constatação de que os hábitos de leitura ou audição por parte, respectivamente, do narrador e do público influenciaram a evolução da narrativa visual, pois que à coincidência entre narração oral e audição, com todas as suas modalidades e variabilidades, própria, por exemplo, do tempo dos bardos e da realização dos poemas homéricos, sucedeu, na época alexandrina e no Império Romano, a dissociação temporal entre o narrador e o seu público, com o novo hábito de ler por conta própria ou fazer ler um texto em voz alta pelo seu secretário ${ }^{29}$. A narrativa visual adquire, a partir de então, o carácter de um sistema de signos que utiliza detalhes descritivos e mecanismos compositivos que tomam o lugar dos tropismos do discurso e do pensamento que são próprios da narração oral ou textual: «esses detalhes servem para identificar o protagonista da acção e para colocar a própria acção no espaço e no tempo, devendo, pois, ser reconhecíveis» ${ }^{30}$. À semelhança do famoso topos horaciano ut pictura poesis, os programas da narrativa visual da Antiguidade visavam criar obras de arte $u t$ historiam simulandum, ou seja, que evocassem «uma atmosfera ou uma ilusão de um facto, de carácter realístico senão mesmo histórico, na medida em que essa atmosfera é, num certo sentido, parte do mundo real» ${ }^{31}$. Para que uma «história» fosse satisfatoriamente representada, era necessário fornecer uma quantidade de informação ancorada na «realidade» ao olhar do espectador, tais como «um repertório de objectos fisicamente existentes no espaço e na luz, ou representações extremamente detalhadas das imagens e dos ambientes que exprimem a história narrada ${ }^{32}$. O observador tornava-se, assim, uma entidade claramente "participante» no processo de construção da própria narrativa, o que leva Brilliant a distinguir, na narrativa visual, três níveis de narrador: o artista, o protagonista da história e, finalmente, o próprio observador ${ }^{33}$.

Compreende-se que, definido nestes termos, um tal programa de «narrativa visual», abundantemente praticado na escultura e pintura romanas, tenha sido objecto de recuperação e releitura pelo Renascimento, não só se tivermos em conta o tantas vezes mal compreendido conceito albertiano de istoria, como já se referiu, mas também tendo em atenção a prática flamenga dos «interiores domésticos» e dos «longes» paisagísticos,

$\infty<\infty<\infty<\infty<\infty<\infty<\infty<\infty<\infty<\infty<\infty<\infty$

28 Richard Brilliant, Visual Narratives. Storytelling in Etruscan and Roman Art, Cornell: Cornell University Press, 1984. Citamos a partir da trad. italiana Narrare per Immagini. Raconti di storie nellarte etrusca e romana, Florença: Giunti, 1987.

29 Idem, ibidem, pp. 9-10.

30 Idem, ibidem, p. 11.

31 Idem, ibidem.

32 Idem, ibidem, pp. 10-11.

33 Idem, ibidem, p. 11. 
âncoras destinadas a situar e a integrar o espectador como leitor da «fábula» ${ }^{34}$. Nesse extraordinário esforço de releitura da herança antiga, o Renascimento viria a «acrescentar» a chave da abóbada de todo o sistema: o «aparelho perspectivo».

Alguns dos modelos de narrativa visual da Antiguidade estudados por Brilliant merecem ser resumidamente referenciados. Um dos mais antigos, característico dos frisos escultóricos dos primeiros templos, é a narrativa linear, ilustrada no friso de episódios sucessivos, mas relativamente independentes entre si, da fundação de Roma, recuperado da Basílica Emília no Forum Romano (meados do séc. I A.C.), enquanto um outro modelo, mais "pictural», consiste na narrativa contínua, que pressupõe uma interacção entre o olho e a mente, discernindo os diversos episódios a partir da repetição da mesma personagem em sequentes momentos da ação ${ }^{35}$. Este modelo pode ser visto no ciclo de frescos, com a mesma temática «fundacional», que outrora decorou o columbarium dos Statilii (segunda metade do séc. I a.C.), no Esquilino, em Roma, hoje no Museu delle Terme: principiando com a fundação de Lavínio e a batalha entre Romanos, Latinos e Rútulos, prosseguia com a fundação de Alba Longa, com o conflito entre Lavínia e Ascânio, com a história de Rheia Sílvia, obrigada a fazer-se vestal, violada por Marte e finalmente condenada, e terminava com a história de Rómulo e Remo. As cenas individualizadas fundiam-se umas com as outras, passando de parede a parede, numa «técnica de condensação narrativa que logra uma globalidade expositiva que consegue atingir, na perfeição, os objectivos patrióticos da representação e ao mesmo tempo prestar homenagem aos titulares do túmulo», os Statilii, que se viam como os sustentáculos da tradição romana ${ }^{36}$.

Com o triunfo do gosto literário e mitológico entre os círculos do patriciado romano, surgiu a decoração doméstica, a fresco, de múltiplas câmaras das domus (casas), com funções diversas, desde a exaltação sensorial e imaginativa (phantasia) provocada pela visão, de acordo com as teorias de Epicuro, até à dramatização dos mais diversos temas da mitologia grega com intenção moralizante ${ }^{37}$. Este novo surto de decoração fresquista, particularmente bem conservada em diferentes casas de Pompeia, baseia-se no aparecimento da cena isolada, com forte carga alegórica, em que o artista «transforma o movimento em imagem estática», numa organização dos episódios colocados «em pendant», quer em subordinação ao modelo retórico de prestígio das controversiae, quer devido à influência da mentalidade inerente às célebres Metamorfoses de Ovídio, que forneceram o material narrativo aos episódios pintados ${ }^{38}$. Por exemplo, na Casa

$\infty<\infty<\infty<\infty<\infty<\infty<\infty<\infty<\infty<\infty<\infty$

34 Cf. E. H. Gombrich, Art and Illusion. A study in the psychology of pictorial representation, Oxford: Phaidon, 1989, p. 131.

35 Brilliant, Narrare per Immagini, cit., pp. 24-26.

36 Idem, ibidem, pp. 27-30.

37 Idem, ibidem, pp. 53-83.

38 Idem, ibidem. 
do Sacerdote Amandus, encontramos dois pares de cenas «em pendant»: de um lado, a Libertação de Andrómeda frente à Queda de Ícaro; do outro, Hércules no Jardim das Hespérides face a Polifemo e Galateia. Embora Brilliant, no inventário que realiza dos conjuntos de frescos «em pendant» das casas pompeianas, não admita regras estritas de emparelhamento, mas tão somente algumas constantes ${ }^{39}$, parece claro que, na sala em questão, se articulavam temáticas alusivas, por um lado, à vingança e à punição, e, por outro, à salvação e ao prémio ou recompensa. Andrómeda sofre a provação porque a sua mãe se havia vangloriado de ser mais bela do que as Nereidas, filhas de Poseidon, mas é salva por Perseu, ao contrário de Ícaro, cuja ambição desmesurada - aproximando-se do Sol e percorrendo meios que os Deuses haviam vedado aos homens - é castigada com a sua precipitação nas águas do Mar, outro desses meios proibidos aos homens, cujo lugar «natural» é, afinal, a Terra ${ }^{40}$. Galateia, uma das Nereidas, vê o seu amado morto pelo gigante Polifemo, cujo amor ela havia desprezado. Em contraste, os árduos trabalhos de Hércules são recompensados, no Jardim das Hespérides, com a oferta das maçãs de ouro.

A experiência culminante da narrativa romana iria ter lugar na escultura, designadamente no modelo de narrativa em espiral inaugurado pela Coluna de Trajano, atribuída ao escultor Apolodoro de Damasco. Combinando a função de depósito das cinzas do Imperador, na base, e de marco glorificador da sua figura, a Coluna de Trajano apresenta 155 cenas em relevo distribuídas ao longo de uma espiral alusivas às campanhas contra os Dácios levadas a cabo vitoriosamente em 101 e 106 d.C.. Em contraste com a minúcia da representação, hiper-realística ao nível de figuras e adereços, mais convencional no plano dos cenários, com o fim de tornar verosímil ou «convincente» a história, seguindo, afinal, as convenções do teatro, a dificuldade de leitura que oferecia ao espectador, agravada, na época, pelo facto de se encontrar, no Forum de Trajano, rodeada, em três dos lados, pelos edifícios da Biblioteca e da Basílica Úlpia, era superada pelos objectivos de mitificação do Imperador, cuja figura, em pose heróica e dominante, aparece repetidas vezes nas cenas narrativas, como já acontecera com o mítico herói fundador Eneias, na secção central da Tabula Iliaca Capitolina ${ }^{41}$. A Coluna atravessava, assim, ambiguamente, os três géneros de narrativa que a literatura antiga viria a codificar ${ }^{42}$ : enquanto columna historiata apresentava-se ao espectador como história de acontecimentos realmente sucedidos; enquanto estratégia de cenografia aproximava-se do que se designava de plas$\mathrm{ma}$, nome dado a certas formas teatrais, em que os acontecimentos figurados, embora

$\infty<\infty<\infty<\infty<\infty<\infty<\infty<\infty<\infty<\infty<\infty<$

39 Idem, ibidem, p. 83.

40 Ver, sobre o modo como este tema foi apropriado na pintura europeia de Quinhentos, nomeadamente num dos «inventores» do género «paisagem», o nosso estudo Fernando António Baptista Pereira, «A Queda de Ícaro de Pieter Brueghel o Velho: estratégias de significação de um tema horaciano» in AA. VV. Estudos de Arte e História. Homenagem a Artur Nobre de Gusmão, Lisboa: Univ. Nova, 1995.

41 Brilliant, Narrare per Immagini, cit., pp. 98-103.

42 Cf. Sexto Empírico, Adversos Grammaticos, 263-264, citado por Brilliant, op. cit., p. 91. 
não reais, são representados de modo similar aos eventos reais; finalmente, enquanto materialização da virtus Trajani, cumpria os objectivos de glorificação da figura imperial, no âmbito do modelo do mythos.

A queda do Império Romano do Ocidente e a formação de uma Europa Cristã acarretaram senão o abandono pelo menos a poderosa transformação da tradição narrativa desenvolvida pela arte romana. Por exemplo, como Gombrich recordou, os ciclos de frescos «narrativos» de Bizâncio não devem ser tomados como imaginativos relatos de acontecimentos passados, mas como marcos na sequência anual das festividades e como uma actualização a-temporal da Vida de Cristo na liturgia da Igreja ${ }^{43}$.

A historiadora americana Marilyn Aromberg Lavin, num brilhante estudo panorâmico, logrou definir os diferentes modelos narrativos presentes na decoração mural das igrejas italianas, na longa duração do século V a 1600, e comparar a respectiva distribuição cronológica ${ }^{44}$. Lavin isolou onze padrões de narratividade que esquematizou em outros tantos diagramas que definem as direcionalidades de leitura ${ }^{45}$. De acordo com a distribuição cronológica dos padrões, os números 1 (dupla paralela), 2 (circular) e 3 (circular inverso, ou seja, ao contrário dos ponteiros do relógio), assim como 4 e 5 (ambos «absidais», com direcionalidade descendente ou ascendente) representam a maioria das soluções paleocristãs e da Alta Idade Média, embora os três últimos tenham sido compreensivelmente repescados no Gótico e no Renascimento. A partir de 1300 e até 1500, predominam os padrões números 8,9 (ambos em contraposição, serial ou linear) e 10 (vertical descendente), embora se registe uma grande variedade de outros padrões, desde os «absidais» ao «circular inverso». O quattrocento é mesmo o período de vigência de todos os modelos recenseados, nomeadamente, além dos já referidos, os números 6 e 7 («cruzados», em horizontal ou vertical) e o 11 (vertical descendente e ascendente), o que, inevitavelmente, corresponde a análoga diversidade de soluções na narrativa e composição retabulares. Finalmente, no século XVI, restringem-se novamente os padrões, sendo os mais utilizados os «circulares» ( $\left.n^{\circ} 2\right)$ e «circulares inversos» ( $\left.n^{\circ} 3\right)$, com alguma representatividade dos «cruzados» (nrs. 6 e 7$)^{46}$.

Ao ter definido estes padrões, a partir do estudo panorâmico levado a cabo, a autora em vão procurou nas fontes escritas a confirmação textual de um qualquer tipo de "programação» e, não a tendo encontrado, colocou a hipótese de tanto o comitente (individual nobre, eclesiástico ou burguês, ou colectivo, como ordens monásticas ou organismos cívicos), como o «ideólogo» (na ocorrência, o teólogo, o universitário ou o humanista), como o próprio artista participarem na definição programática, ou seja, na

$\infty<\infty<\infty<\infty<\infty<\infty<\infty<\infty<\infty<\infty<\infty<$

43 Cf. E. H. Gombrich, Art and Illusion, cit., p. 125.

44 Marilyn Aromberg Lavin, The Place of Narrative. Mural Decoration in Italian Churches, 431-1600, Chicago e Londres: Chicago University Press, 1990.

45 Idem, ibidem, pp. 7-11.

46 Idem, ibidem, p. 8. 
escolha do padrão narrativo a adoptar ${ }^{47}$.

Por outro lado, ao nível da economia narrativa, perante uma tão grande diversidade de padrões narrativos, que se não limitavam a uma função meramente ilustrativa da história bíblica e das vidas dos mártires e santos, mas contemplavam também questões de dogma, moralidade e poder, a autora distinguiu três níveis ou mesmo fases de abordagem da narratividade: o espectador conhece o fio condutor da história e reconhece-o nas unidades narrativas; mas, quando estas estão deslocadas segundo diferentes padrões, o espectador reconhece o rearranjo cronológico e, em consequência, infere novos significados das diversas combinações de unidades narrativas, por sua vez utilizadas como componentes de novas mensagens ${ }^{48}$.

Ao longo do estudo que terminámos em 2001, sobre os retábulos portugueses da primeira metade do século XVI ${ }^{49}$, demonstrámos que a narrativa retabular tirou partido expressivo e ao nível da significação não apenas das direccionalidades horizontais de leitura das istorie, mas também da organização compositiva dos painéis na armação retabular, segundo eixos verticais e diagonais, numa estratégia de permanente enriquecimento e diversificação das leituras propostas.

É importante lembrar que, desde o final da Antiguidade, a divisão da narrativa em unidades - sobrepondo-se aos anteriores e já referidos esquemas da narrativa linear, contínua e em espiral - acompanhara, senão mesmo derivara, da substituição do rolo pelo códice. Toda a narrativa posterior se vai basear numa sucessão/articulação de unidades que se recortam como cenas/episódios.

A grande explosão narrativa da Idade Média, antes da revolução operada pela pintura do século XV, na Flandres e na Itália, vai, contudo, ter lugar a Norte dos Alpes, com o aparecimento e generalização dos grandes complexos de vitrais das catedrais góticas. Com efeito, de acordo com os estudos inovadores de Wolfgang Kemp sobre a narratologia do vitral gótico, «o compulsivo desejo de narrativa que caracterizou este período [os inícios do século XIII], levou a cabo uma tão completa transformação dos materiais e dos meios que só pode ser comparável à que foi realizada na grande fase seguinte da pintura narrativa constituída pelos ciclos de frescos da Itália quatrocentista» ${ }^{50}$. As imagens das gigantescas, pequenas ou médias janelas e rosáceas dos grandes templos do Gótico, atingindo, por exemplo, no caso da Catedral de Chartres, um total original de 185 complexos figurativos, de que restam 152, numa extensão de mais de 2000

$\infty<\infty<\infty<\infty<\infty<\infty<\infty<\infty<\infty<\infty<\infty<$

47 Idem, ibidem, p. 5.

48 Idem, ibidem, p. 6.

49 Fernando António Baptista Pereira, Imagens e Histórias de Devoção..., cit..

50 Wolfgang Kemp, The Narratives of Gothic Stained Glass, Cambridge, Cambridge University Press, 1997, p. 3. 
metros quadrados ${ }^{51}$, têm de ser lidas de acordo com a própria ordenação dessas estruturas arquitectónicas, à qual diligente e criativamente se submeteram os artistas, traduzindo não apenas uma sequência narrativa mas também um instrumento de reflexão ${ }^{52}$.

A origem de um dos principais modelos narrativos estudados por W. Kemp - o da narrativa em sequências, em que, a cada registo horizontal corresponde uma ação, com um motivo de encerramento no fim de cada sequência, tal como se vê na janela do Filho Pródigo da Catedral de Chartres - pode encontrar-se em vitrais românicos da segunda metade do século XII, como o célebre vitral da Encarnação ou do Natal, na mesma catedral. Embora, no primeiro registo (Anunciação, Visitação e Natividade), as três cenas correspondam a três diferentes acontecimentos, no registo seguinte (a leitura faz-se sempre de baixo para cima), o segundo e terceiro encasamentos encontram-se ligados pela figura de Herodes (com os seus conselheiros e diante dos Magos), o mesmo acontecendo com o primeiro e segundo do terceiro registo (a Epifania), para alcançar a fusão total, em perfeita sequência, no décimo terceiro registo, com a Entrada em Jerusalém $m^{53}$.

Um outro modelo - o da narrativa através das figuras, em que o leitor/espectador está inteiramente dependente do que narram os próprios elementos figurativos, na estruturação vertical da própria da janela - é atingido, na sua máxima perfeição, na Catedral de Bourges, no vitral da Parábola do Filho Pródigo. Liberta dos constrangimentos técnico-construtivos de seccionamento horizontal que limitavam o vitral de tema análogo de Chartres, a janela de Bourges organiza a «história» de forma especular e antitética, fazendo corresponder ações ou modelos compositivos e opondo temas. À excepção do registo inferior, com os doadores - os tanoeiros - e do registo superior, com a conciliação entre os dois Filhos, sob a égide do Pai, todos os outros registos têm, numa certa regularidade «rítmica», uma contrapartida temática ou formal: por exemplo, a sequência da «festa» no bordel é quebrada com a expulsão do Filho Pródigo; enquanto o banquete que assinala o regresso a casa é interrompido pela chegada do Filho mais velho. Como diz Kemp, «cada cena é espelhada num eixo que separa diferentes ordens de existência e de valores: bem e mal, casa e mundo exterior, cima e baixo, antes e depois, seriedade e deboche» ${ }^{54}$.

Finalmente, encontramos a narrativa tipológica, que faz emparelhar e cruzar linhas narrativas do Antigo e do Novo Testamento, na base da repetição e analogia ou enquanto cumprimento do profetizado, funcionando as narrativas novi-testamentárias como tema dominante e as vetero-testamentárias como elementos subsidiários ${ }^{55}$. A

$\infty<\infty<\infty<\infty<\infty<\infty<\infty<\infty<\infty<\infty<\infty<$

51 Cf. Idem, ibidem.

52 Cf. Idem, ibidem, pp. 3-5.

53 Cf. Idem, ibidem, pp. 25-27.

54 Cf. Idem, ibidem, pp. 32-33.

55 Cf. Idem, ibidem, pp. 42-43 
fonte deste modelo narrativo parece residir na iluminura otoniana. Assim acontece na inicial iluminada «I» (de In principio...) da célebre Bíblia de Stavelot (última década do século XI, Museu Britânico): no eixo central dispõem-se, de baixo para cima, temas da Vida de Cristo; pela esquerda, até ao topo, temas do Genesis e dos Actos dos Apóstolos e, por último, a Parábola dos trabalhadores da Vinha, numa sequência que faz suceder a temas ante legem, temas sub lege e temas sub gratia; finalmente, no eixo da direita, as horas canónicas ${ }^{56}$.

Os mais completos e extensos ciclos narrativos tipológicos do vitral gótico ducentista estão particularmente ligados às parábolas, não só porque estas são claramente «estórias» contadas por Cristo aos ouvintes, encerrando importantes verdades da Fé, como se prestavam especialmente à exegese teológica ${ }^{57}$. O vitral do Bom Samaritano, na catedral de Chartres, semelhante na estrutura ao vitral do Filho Pródigo de Bourges, atrás tratado, não será um «puro» exemplo de modelo tipológico, mas associa, num eixo vertical com paralelismos «rítmicos», a parábola ao tema da Criação e Queda do Homem, insistindo no paralelo Adão / homo viator ${ }^{58}$, dentro da perspectiva cristológica de superioridade da Nova Lei sobre a Antiga.

A partir do século XIII, quer a tradição fresquista, predominante na Itália, quer a do vitral, preferida em França e na Inglaterra, vão ser confrontadas com a emergência do retábulo e, consequentemente, da narrativa retabular. Registemos que os mais antigos quadros «verticais» colocados sobre e atrás da mesa de altar (esta a origem do próprio termo «retábulo» a partir da expressão latina retro tabulum, por detrás da mesa do altar), surgidos na Itália, substituindo os formatos «horizontais» directamente derivados dos frontais de altar, mais comuns na Espanha e na Europa do Norte, apresentam, ao centro, «imagens de devoção» de S. Francisco de Assis rodeadas de pequenas cenas narrativas dos seus milagres e dos passos mais significativos da sua Vita, como vemos no retábulo de S. Francisco, de Bonaventura Berlinghieri, datado de 1235, em que a leitura dos pequenos episódios é feita de baixo para cima. Antes de terminar o século, o Mestre de Cesi, anónimo toscano, no tríptico da Assunção da Virgem, colocou, no painel central, uma cena narrativa, precisamente a que dá o título ao retábulo e, nos volantes, as subdivididas cenas, inspiradas na Legenda Aurea, de Jacques de Voragine, do anúncio, despedida, morte e funerais de Maria ${ }^{59}$. A direccionalidade de leitura é feita de cima para baixo e da esquerda para a direita, seguindo os hábitos de leitura do texto escrito.

O trecento e as décadas iniciais do quattrocento, sobretudo na Itália, mas também em Espanha e na Alemanha, vão desenvolver o gosto pelos polípticos, verdadeiras estruturas arquitectónicas ao gosto gótico, de registos sobrepostos, enquadrando pintu-

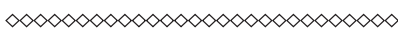

56 Cf. Idem, ibidem, pp. 50-52.

57 Cf. Idem, ibidem, p. 66.

58 Cf. Idem, ibidem, pp. 74-77.

59 Cf. Dominique Thiébaud, «Maître de Cesi» in AA. VV. Poliptiques, Paris: Louvre, 1990, pp. 52-53. 
ras de diferentes formatos. O registo principal é constituído, geralmente, por três, cinco ou sete painéis, sendo o central de maiores dimensões; em altura, apresentam dois ou três registos, terminando o do topo em formas triangulares à maneira de gablete e contemplando na base, frequentemente, uma predela ${ }^{60}$. Nas catedrais e nalgumas igrejas monásticas surgiram polípticos pintados nas duas faces, uma virada para a nave e para os fiéis e outra virada para o coro e para o clero, disposto atrás do altar ${ }^{61}$. Alguns dos primeiros exemplos destes polípticos de dupla face foram devidos a Giotto - o Políptico Stefaneschi, ca. 1330, com cenas dos martírios dos Apóstolos Pedro e Paulo ladeando um Cristo em Magestade - e a Duccio - a célebre Maestá, realizada para a Catedral de Siena em 1308-11, com cinquenta cenas da Paixão pintadas no reverso, numa altura total de $4,95 \mathrm{~m}$ e uma largura de $4,40 \mathrm{~m}^{62}$.

A partir dos finais do século XIV, tanto em Itália como em Espanha, dá-se um extraordinário desenvolvimento em altura das armações retabulares, com sobreposição de registos narrativos e, ao nível do registo central, com a representação de figuras de corpo inteiro em escala quase natural; em Valência e na Catalunha, a própria estrutura do «guarda-pó» é «historiada» ${ }^{63}$.

Iconograficamente, os polípticos combinam as «imagens de devoção» de Cristo assim como da Virgem e de outros múltiplos intercessores (como os Santos), exigidas por uma clientela piedosa que a eles recorre para solicitar protecção e defesa, individual ou colectiva, contra males do espírito e do corpo, com as cenas narrativas, alimentadas pelas glosas bíblicas e pela hagiografia, cada vez mais vulgarizadas. Um dos exemplos porventura cimeiros dessa articulação de diferentes registos imagéticos numa multiplicidade de painéis, sobrepostos em diversas fiadas, e pintado nas duas faces, seria dado pelo hoje desmembrado e disperso retábulo de Borgo San Sepolcro, a mais cara das realizações picturais do quattrocento italiano, executado pelo pintor de Siena Stefano di Giovanni, dito o Sassetta, entre 1437, data da encomenda, e 1444, data da conclusão do assentamento $^{64}$. O políptico levantava-se sobre o altar, sob o qual repousavam os restos mortais do Bem-aventurado Ranieri Rasini, irmão leigo franciscano que era objecto de importante culto local. Na face virada para os fiéis, representava, no registo central, a Madona com o Menino e Anjos, ladeada pelo Precursor e pelo Bem-aventurado Ranieri, à esquerda, e por S. João Evangelista e por Santo António de Pádua, à direita. A predela era composta por cenas da Vida e Milagres do Bem-aventurado Ranieri. No reverso,

$\infty<\infty<\infty<\infty<\infty \times \infty \times \infty \times \infty \times \infty<\infty<$

60 Cf. AA. VV. «Quelques exemples de poliptiques, du Moyen Âge au XVIIe siècle» in AA. VV. Poliptiques, cit., p. 22. Sobre as origens do retábulo esculpido ver o importantíssimo catálogo AA. VV. Les Premiers Retables (XIIe- début du XVe siècle). Une mise en scène du sacre, Paris: Louvre, 2009.

61 Cf. Idem, ibidem.

62 Cf. Idem, ibidem.

63 Cf. Idem, ibidem, p. 25.

64 Cf. Dominique Thiébaud, «Sassetta, Poliptique de Borgo Sansepolcro» in AA. VV. Poliptiques, cit., pp. 79-85, com bibliografia adicional sobre a documentação e a iconografia. 
virado para o coro, o políptico oferecia uma mais acentuada carga narrativa, certamente destinada à edificação do clero: ao centro, um painel de grandes dimensões com o Êxtase de S. Francisco, ladeado por duas fiadas sobrepostas de episódios da sua Vita; na predela, cenas com a Paixão de Cristo ${ }^{65}$, reforçando o tema de exaltação do Patriarca da Ordem Seráfica resumido no tópico Franciscus alter Christus ${ }^{66}$.

Todavia, a complexa estrutura do monumental políptico de Sasseta, à data da sua execução, que se estendeu, como vimos, por sete anos ${ }^{67}$, vir-se-ia confrontada com o aparecimento e generalização de novos modelos de organização retabular ao gosto renascentista. De facto, o aparecimento da «pala» de altar na cena florentina, logo na década de 1430, com o célebre retábulo da Anunciação, de Fra Angélico, impõe a unificação retabular, em que a própria estrutura arquitectural, de carácter renascimental, funciona apenas como moldura, através da qual se tem acesso à representação principal unifica$\mathrm{da}^{68}$. Situação próxima pode ser vista, na mesma época, a Norte dos Alpes, no célebre Políptico do Cordeiro Místico, de Hubert e Jan Van Eyck, terminado em 1432, em que dois dos registos constituem duas cenas unificadas, distribuídas por cinco e quatro painéis de suporte, respetivamente: a Adoração do Cordeiro Místico, com o retábulo aberto, e a Anunciação, com o retábulo fechado. Neste último caso, o pintor chegou ao ponto de fazer «projectar» as sombras da própria moldura no pavimento da cena, reforçando o efeito de «janela» que a armação retabular acaba por assumir ${ }^{69}$.

Mesmo quando a armação retabular cresce em altura e se complexifica, em vá-

$\infty<\infty<\infty<\infty<\infty<\infty<\infty<\infty<\infty<\infty<\infty<\infty$

65 Esta localização de temas do ciclo da Paixão, que, à primeira vista, se julgariam destinados a registos de coroamento, encontra-se noutros exemplos, quer em Itália, quer em Espanha, quer no Norte da Europa. Vamos encontrá-la, em Portugal, no retábulo-mor da Sé de Évora, segundo a nossa proposta de reconstituição. Cf. Fernando António Baptista Pereira, Imagens e Histórias de Devoção..., cit., pp. 210-218.

66 Cf. Dominique Thiébaud, «Sassetta, Poliptique de Borgo Sansepolcro», cit., pp. 79-80.

67 É importante reforçar este aspecto do tempo de execução, sempre que documentado, como é o caso, para evitar insustentáveis datações, como as que foram, em vários momentos, propostas recentemente para um complexo políptico como o do Altar de S. Vicente da Sé de Lisboa, de Nuno Gonçalves (de cerca de 146871), cujos painéis remanescentes se podem ver no Museu Nacional de Arte Antiga, em Lisboa. Segundo um livro recente, que «lê» a data de 1445 numa tira decorativa existente na bota de uma das personagens do «Painel do Infante», o retábulo, que os autores limitam aos seis painéis da chamada «Veneração», teria de ter sido pintado em apenas dois-três anos, uma vez que os exames dendrocronológicos recentemen 1 te realizados por Peter Klein mostram que, na mais recuada das hipóteses, os suportes em madeira de carvalho só estariam prontos para receber uma criação pictural a partir de 1442, embora aquele cientista se incline para uma data preferencial de 1448, o que, evidentemente, inviabiliza a data supostamente «lida» na tira. Sobre esta obra-prima da Pintura Portuguesa de todos os tempos ver Fernando António Baptista Pereira, Imagens e Histórias de Devoção..., cit., pp. 114-170, e «Istoria e Retrato no Retábulo de S. Vicente de Nuno Gonçalves» in Arte Teoria, nº 12/13 (número de Homenagem a António Rodrigues), Lisboa: CIEBA, 2010, pp. 161-183.

68 Cf. Poliptiques, cit., p. 30.

69 A bibliografia sobre este extraordinário Políptico, obra máxima da Pintura de todos os tempos, é vastíssima. Ver o mais recente ponto da situação em Caterina Limentani Virdis e Mari Pietrogiovanna, Retables. L’âge gothique et la Renaissance, trad. franc., Paris : Citadelles \& Mazenod, 2001, pp. 50-69. 
rios andares de registos iguais ou desiguais e contemplando um frontão de coroamento e predela em baixo, os pintores italianos do quattrocento como Mantegna, Giovanni Bellini ou Cosimo Turá não deixaram de reconstituir, no interior deste «enquadramento fraccionado», a unidade espacial da representação ${ }^{70}$. A lição de «unificação» da cena dos irmãos Van Eyck foi aprofundada por Roger van der Weyden no não menos célebre políptico do Juízo Final de Béaune, iniciado em 1443 e concluído cerca de 1451, provavelmente já depois da viagem do pintor a Itália ${ }^{71}$.

O desenvolvimento dos modelos retabulares, ao longo dos séculos XV e XVI, vai conhecer acentuados regionalismos. Enquanto, na Flandres, se impõe o modelo do tríptico de volantes móveis, que permanece fechado e só se abre para a celebração eucarística e em ocasiões festivas, a Itália e a Península Ibérica permaneceram fiéis aos retábulos fixos, visíveis na sua totalidade ${ }^{72}$, salvo quando a liturgia determinava a sua ocultação, correndo-se cortinas, segundo o que alguma documentação dá a entender ${ }^{73}$.

$\mathrm{Na}$ Alemanha, pelo contrário, generalizou-se um modelo de tríptico de volantes duplos, fechando-se estes sucessivamente sobre o painel central, por vezes uma estrutura esculpida: apresentava-se fechado todos os dias, excepto aos domingos, em que se abriam os volantes exteriores, mostrando a máxima extensão pintada com numerosas cenas narrativas, como acontece nos retábulos de São Wolfgang, de Michael Pacher, realizado entre 1471 e 1481, e de Güstrow, de 1520, sendo o núcleo central, esculpido e dourado, apenas posto a descoberto nas grandes festas ${ }^{74}$. O exemplo cimeiro da fusão deste modelo com a tendência «humanista» italianizante da cena unificada vai ser protagonizado pelo magnífico Retábulo de Issenheim, de Mathias Grünewald, executado entre 1511 e 1517, «em que o visionário artista, abandonando toda a compartimentação vertical ou horizontal, suprime a moldura intermédia na junção dos volantes para obter amplas cenas de composição contínua que nenhuma estrutura interrompe - realização extrema pela riqueza de possibilidades e negação final do próprio políptico, uma vez que as cenas centrais, em posição fechada ou intermédia, fazem esquecer que são pintadas em distintos painéis» ${ }^{75}$.

Finalmente, nos reinos que então constituíam a Espanha, a evolução dos modelos retabulares, bem estudada, no que respeita aos séculos XIV e XV, por Judith Berg Sobré,

$\infty<\infty<\infty<\infty<\infty<\infty<\infty<\infty<\infty<\infty<\infty<$

70 Cf. Poliptiques, cit., p. 30.

71 Cf. Otto Pächt, Early Netherlandish Painting. From Rogier van der Weyden to Gerard David, Londres: Harvey Miller Publ., 1997, pp. 40-49.

72 Cf. Poliptiques, cit., p. 33. Ver, também, Judith Berg Sobré, Behind the Altar Table. The Development of the Painted Retable in Spain, 1350-1500, Columbia: Miss. Univ. Press, 1989, pp. 75-168.

73 Ver documentação referida em Fernando António Baptista Pereira, Imagens e Histórias de Devoção..., cit., p. 111.

74 Cf. Poliptiques, cit., p. 38.

75 Poliptiques, cit., p. 39. Ver, também, Caterina Limentani Virdis e Mari Pietrogiovanna, Retables..., cit., pp. 220-237. 
e, no que toca ao XVI, por Rogelio Buendía e Roman Hernández Nieves ${ }^{76}$, mostra-nos a passagem de armações de talha gótica dominantemente tripartidas, com cena central de maiores dimensões ladeada por cenas narrativas sobrepostas, protegidas por guarda-pós e enriquecidas por predelas que podem ser acompanhadas por portas, como acontece com o Retábulo do Condestável, de Jaume Huguet, passando por monumentais conjuntos como o da Catedral Vieja de Salamanca (retábulo de 1445, com cinquenta e três pinturas, afeiçoado à ábside românica da igreja, da autoria de Nicolás Florentino) até desembocarmos em estruturas de forte carga arquitectural já moldada pelo emergente gosto renascentista, enquadrando pinturas com cenas narrativas ou uma combinação de pinturas e de nichos para esculturas, como acontece no pouco conhecido retábulo da Virgem de Castrillo de Matajudíos, em que uma imagem romano-gótica foi integrada numa armação «ao romano», com pinturas narrativas, em fiadas sobrepostas com leitura de baixo para cima, e predelas de «meias figuras», tudo ainda ao gosto flamengo ${ }^{77}$.

\section{Istoria e espaço-tempo figurativo na pintura do Renascimento ao Barroco}

Regressemos, então, ao «quadro-janela» do Renascimento, tornado possível pela perspectiva artificialis, tópico com que abrimos este texto. Foram vários, segundo Kim Veltman, os «instrumentos» usados, ao longo dos séculos XV a XVII, como auxiliares de construção da perspectiva, nomeadamente o que L. B. Alberti designou por «velum», «velo» ou «véu» e que também é conhecido, precisamente, por «método da janela». $\mathrm{O}$ célebre teórico humanista descreve-o no Livro II do seu tratado e reclama a sua paternidade, ainda que se saiba que a autoria do mesmo se deve a Brunelleschi ${ }^{78}$. Com efeito,

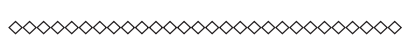

76 Ver Judith Berg Sobré, op. cit., Rogelio Buendía, «Sobre los orígenes estructurales del retablo» in Revista de la Universidade Complutense de Madrid, n 20, Madrid, 1973, pp. 17-40, Roman Hernández Nieves, Retablística de la Baja Extremadura Siglos XVI-XVIII, Mérida, 1991, e Agustín Lázaro López, Museo del Retablo, Burgos, 1993, pp. 87-89. Ver, ainda, sobre a evolução do retábulo em Portugal, os nossos estudos: Fernando António Baptista Pereira, Imagens e Histórias de Devoção..., cit.. ; Fernando António Baptista Pereira, «Descidas do Espírito Santo em programas iconográficos retabulares dos séculos XV e XVI», in Artis n 3, Lisboa: FLUL, 2005, pp. 161-197; e Fernando António Baptista Pereira, «O Retábulo-mor do Convento de Jesus de Setúbal no contexto dos conjuntos retabulares atribuídos à oficina do Pintor Régio Jorge Afonso» in Fernando António Baptista Pereira e Maria João Cândido (eds.), Retábulo do Convento de Jesus de Setúbal ca. 1517/19-1530, Setúbal, CMS, 2013, pp. 15-47.

77 Cf. Poliptiques, cit., p. 41.

78 Ver, sobre as primeiras experiências de Brunelleschi no campo da perspectiva, Martin Kemp, The Science of Art. Optical themes in western art from Brunelleschi to Seurat, New Haven: Yale Univ. Press, 1989, pp. 9-52, e Hubert Damish, L'Origine de la Perspective, Paris: Flammarion, 1987, especialmente pp. 101-146. O livro de Damish veio recolocar o problema histórico e filosófico das origens da perspectiva renascentista, a partir de uma revisão da abordagem clássica de Erwin Panofsky, em La perspective comme forme symbolique [1ª ed. alemã 1924-25], trad. franc., com prefácio de Marisa Dalai Emiliani, Paris: Minuit, 1975. Já em 2001, 
na versão do mesmo «em língua vulgar», destinada ao uso das oficinas de pintura da sua época, em que vários passos mais «teóricos» da obra foram resumidos ou mesmo sacrificados, Alberti omitiu a referência directa ao facto de ter sido o primeiro a usá-lo. Eis o passo do Livro II do De Pictura em que se descreve o «método da janela»: «É preciso, pois, aplicar-se ao traçado dos contornos e para o obter perfeitamente acho que se não pode encontrar algo de mais prático do que aquele véu que tenho por hábito, com os meus amigos, de chamar «intersecção» e que fui o primeiro a inventar. Faz-se assim: é um véu tecido de fios muito finos e pouco cerrados, tingido de uma cor qualquer, dividido por fios mais grossos no número de quadrados que se quiser e esticado numa grade. Coloco-o entre o corpo a representar e o olho, de modo que a pirâmide visual penetre através da finura do véu. A intersecção do véu oferece numerosas vantagens, em primeiro lugar porque apresenta sempre as mesmas superfícies imóveis, depois, porque, depois de teres colocado as tuas referências, tu podes reencontrar logo a ponta da pirâmide, o que é muito difícil de obter sem o plano de intersecção. Enota que é impossível reproduzir uma coisa pela pintura se ela não conservar sempre a mesma face para aquele que pinta. De facto, as coisas pintadas, conservando sempre a mesma face, igualam melhor os seus modelos do que as coisas esculpidas. Sabe, ainda, que se modificares a distância e a posição do centro, a coisa vista parecerá ela própria alterada. O véu de que falei prestará o serviço não negligenciável de manter uma coisa sempre idêntica ao olhar» ${ }^{79}$.

Nesta longa descrição do método de representação inaugurado pela perspectiva artificialis está perfeitamente consignada a «invenção» do próprio espectador cujo olhar, ou ponto de partida da pirâmide visual, é, finalmente, especular face ao ponto de fuga da composição. Por isso, como disse Jean-Louis Déotte, o fundamento do aparelho perspectivo que Brunelleschi e Alberti instauraram reside numa atitude ontológica radicalmente nova, que ninguém em particular tomou mas que revolucionou o mundo e a sua história, a saber, «que para racionalizar o espaço foi preciso ter antes decidido que doravante o mundo se dava numa vista, que ele era visível, e não mais lisível, como na acepção medieval» ${ }^{80}$.

Esta mudança radical de atitude perante a imagem - inaugurando, na radicalidade da teoria, uma vez que, na prática, ela vinha sendo lentamente ensaiada desde o trecento, a moderna concepção do espaço contínuo, mensurável e infinito ${ }^{81}$ - arrastou consigo novos modos de representação do binómio espaço/tempo e, em consequência, veio recolocar o problema da narratividade na representação artística.

Depois do florescimento da narrativa na Arte Romana e do seu relativo «ocaso»

Eric Valette publicou uma nova revisão do problema em La perspective à l'ordre du jour: fonctionnents symboliques et esthétiques de la perspectiva artificialis, Paris: L’Harmattan, 2001.

79 Alberti, De La Peinture / De Pictura, cit., Livro II, pp. 146-148 (tradução nossa).

80 Jean-Louis Déotte, Lépoque de l’appareil perspectif, cit., p. 20.

81 Erwin Panofsky, Renascimento e Renascimentos, cit., p. 171. 
durante a Alta Idade Média, o Gótico (re)introduzira, em grande escala, uma pluralidade de modelos de narratividade na Arte, tal como antes referimos, utilizando diversos processos compositivos, desde a contiguidade e a justaposição de cenas até à diferenciação de níveis e à junção de motivos secundários ${ }^{82}$, quase sempre reduzidos aos planos principais, como pode ver-se na iluminura, na tumulária ou nos pequenos altares de devoção privada, em marfim.

De resto, quanto ao conceito de istoria, Alberti, no Livro II do seu Tratado, esclarece que «O maior trabalho do pintor não é fazer um colosso, mas uma istoria. E o seu engenho terá muito mais mérito numa istoria do que num colosso. As partes da istoria são os corpos, a parte do corpo é o membro e a parte do membro é a superfície. As primeiras partes de uma obra são as superfícies, porque delas são feitos os membros, dos membros os corpos e dos corpos a istoria, que constitui o último grau de acabamento da obra do pintor» ${ }^{83}$.

Finalmente, Alberti associa explicitamente o conceito de istoria ao de ação: «Eu diria que uma istoria é muito abundante quando ela mostrar ao mesmo tempo cada coisa no seu justo lugar, velhos, homens, adolescentes, crianças, mulheres, meninas e criancinhas, animais domésticos, cães, passarinhos, cavalos, carneiros, casas, campos, e louvarei toda essa abundância se ela convier à acção. Com efeito, quanto mais os espectadores são demorados pelas coisas que observam mais agradecem ao pintor a sua abundância» ${ }^{84}$. O que está em causa é, assim, como sublinhou Jean-Louis Déotte, «um lugar cénico, de representação, que supõe uma unidade espacial, uma continuidade do espaço, e não é senão nessas condições que uma história pode ser narrada em pintura ${ }^{85}$.

Com as possibilidades abertas pela perspetiva, a capacidade de representar os diversos tempos de uma istoria no unificado espaço de representação pareciam infinitas. E assim veio a acontecer, logo no arranque da experiência renascentista, tanto na Itália, quer na teoria, quer na prática artística (veja-se, por exemplo, o caso da «Porta do Paraíso» de L. Ghiberti, no Baptistério de Florença) ${ }^{86}$, como na Flandres (por exemplo, no

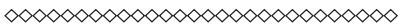

82 Cf. Sixten Ringbom, Les Images de Dévotion (XII-XVe siècles), Paris: Monfort, 1995, pp. 41-85. Ver, do mesmo autor, sobre a distinção entre «imagem de devoção» e "cena narrativa» ou entre simbola e historiai, De L'icône à la scène narrative, Paris: Monfort, 1997, pp. 9-22.

83 Alberti, De La Peinture / De Pictura, cit., Livro II, p. 158 (tradução nossa). Algumas páginas antes (p. 152), Alberti invertera a abordagem, começando com uma frase quase idêntica: «a maior tarefa do pintor é $a$ istoria» («Amplissimum pictoris opus historia»), para, logo de seguida, acrescentar: «as partes da istoria são os corpos, a parte do corpo é o membro e a parte do membro é a superfície» ("historiae partes corpora, corporis pars membrum est, membri pars est superficies»), num método retórico de vai do todo para as sucessivas unidades que o compõem.

84 Alberti, De La Peinture / De Pictura, cit., Livro II, p. 170.

85 Jean-Louis Déotte, Lépoque de l'appareil perspectif, cit., p. 145.

86 Este problema apenas foi, até à data, no que respeita ao Renascimento italiano, objecto de uma abordagem aprofundada por Lew Andrews, em Story and Space in Renaissance Art. The Rebirth of continuous narrative, Cambridge: Cambridge Univ. Press, 1995. 
Tríptico dos Sete Sacramentos de Rogier van der Weyden). Todavia, o primado concedido à figura humana e à "pose litúrgica» que a caracteriza na imagem devocional ${ }^{87}$, principalmente na Flandres, mas também na Itália, ao longo de todo o século XV, retardou, por algum tempo, a plena consciencialização da importância e premência de uma nova imagem narrativa. Com efeito, é possível detectar um momento que rotulámos de icónico na pintura europeia, ao longo do século XV, que parte do típico ethos das figuras de Jan Van Eyck ou da «pose litúrgica» de algumas das personagens de um Hans Memling, mas que também é discernível na "negação da ação» tão típica dos famosos «Painéis de S. Vicente» de Nuno Gonçalves ${ }^{88}$ e no «tempo congelado» ou mesmo na sublimação do tempo que caracteriza a pintura de um Piero della Francesca, e se confronta, por um lado, com as exigências da devotio moderna a que um Rogier van der Weyden responde com cenas narrativas em close up inspiradas numa antiga tradição icónica medieval (de referente bizantino), e, por outro, com a emergência dos grandes ciclos narrativos, na Itália (Carpaccio, Bellini) e entre os «petits maîtres» da Flandres, conjuntos esses suscitados por uma visão cada vez mais teatral e verosímil do estatuto e papel da imagem. Em alguns dos artistas mencionados conflituam tendências opostas, quer em diferentes obras, em resposta a distintos comitentes, quer na mesma obra. Por exemplo, no célebre Santo Agostinho de Piero della Francesca, proveniente ao Políptico dos Eremitas de Santo Agostinho de Borgo Sansepolcro ${ }^{89}$ e hoje no Museu Nacional de Arte Antiga, a figura majestosa do Doutor da Igreja, «icónica» e impassível, contrasta com a explosão de «imagens de devoção» e episódios narrativos que povoam a «mitra» e a «capa de asperges» como verdadeiros «quadros dentro do quadro».

Se o Homem do Renascimento concebeu e realizou plasticamente a unidade de espaço, graças, como acabamos de ver, às possibilidades abertas pela perspectiva artificialis, não logrou sempre aproximação identicamente unitária da categoria de tempo: são frequentes as multiplicidades de tempos ao nível do enunciado num mesmo enquadramento espacial. É clássico o exemplo do painel das Alegrias da Virgem, de Memling, hoje na Pinacoteca de Munique. Nesta composição, o genial pintor de Bruges povoou toda uma mesma paisagem urbana, rural e até fluvial-marítima, observada à maneira de voo de pássaro, com os diversos episódios da Infância de Jesus, da Vida Gloriosa de Cristo e da Morte e Assunção da Virgem, distribuídos por diversos «palcos», quer estes estejam enquadrados por fragmentos da paisagem rural ou urbana, quer por compartimentos de casas. Numa evidente demonstração do princípio do «quadro-janela», que, na ocor-

$\infty<\infty<\infty<\infty<\infty<\infty<\infty<\infty<\infty<\infty<\infty<\infty<$

87 Cf. Paul Philippot, Pénétrer l'Art. Restaurer l'Oeuvre, Groninge: 1990, pp. 73-110.

88 Cf. a nossa leitura do retábulo do altar de S. Vicente da Sé de Lisboa, atribuído por Francisco de Holanda a Nuno Gonçalves, na nossa dissertação de doutoramento, já citada, Imagens e Histórias de Devoção.... cit., pp. 114-170, e em «Istoria e Retrato no Retábulo de S. Vicente de Nuno Gonçalves» in Arte Teoria, n 12/13 (número de Homenagem a António Rodrigues), Lisboa: CIEBA, 2010, pp. 161-183.

89 Sobre este políptico ver AA. VV. Il Polittico Agostiniano di Piero della Francesca, Milão, Museo Poldi Pezzoli, 1996. 
rência, remontava ao Tríptico de Mérode de Rober Campin (Mestre de Flémalle) ${ }^{90}$, os doadores do painel estão representados «assistindo» à Natividade, através de uma janela gradeada, ou ao Pentecostes, como se a «quarta parede» da Sala não existisse, apresentando-se, assim, a cena através deste esquema voyeurístico, que repete, pela citação directa, o próprio lugar do espectador.

Também em Portugal encontramos casos paradigmáticos como o que acabamos de referir. Um dos mais famosos é a pintura nórdica intitulada Panorama de Jerusalém, oferecida pelo Imperador Maximiliano de Habsburgo a sua prima D. Leonor e que esta legou ao Mosteiro da Madre de Deus, em Lisboa, onde ainda hoje se encontra. O painel apresenta uma sequência dos diversos passos da Paixão de Cristo distribuídos pelos diferentes espaços urbanos - exteriores e interiores - de uma imaginária Jerusalém, «representada» perante o olhar devoto da Rainha, retratada num dos cantos do painel (e, naturalmente, perante o dos espectadores que com ela se identificam). Lew Andrews identificou um livro intitulado Giardino de orationi, escrito em 1454 e amplamente difundido nos séculos XV e XVI, que instruía os devotos a meditarem e a recordarem os episódios da Paixão, nos seguintes termos: «Para melhor imprimir a História da Paixão no vosso espírito e memorizar cada episódio dela, ajuda e é necessário fixar os lugares e as pessoas no vosso espírito: uma cidade, por exemplo, que pode ser a cidade de Jerusalém, tomando para este fim uma cidade que é bem vossa conhecida, Nesta cidade encontrem os sítios em que todos os episódios da Paixão tiveram lugar...» $»^{91}$. Será difícil encontrar melhor descrição do «programa iconográfico» do Panorama de Jerusalém!

$\mathrm{Na}$ novelística portuguesa coeva são frequentes as referências a imagens ou histórias que, através da narração, se «representam perante os olhos» dos interlocutores, como verdadeiros quadros, e, por extensão, perante os dos leitores e/ou eventuais ouvintes. Num dos mais famosos exemplos, a novela Saudades, que Bernardim Ribeiro terá composto nos últimos anos da sua vida (ou seja, nos anos trinta de Quinhentos), mais conhecida por Menina e Moça, a protagonista inicial - a Menina - anuncia o enredo do livro - que lhe irá ser narrado pela Dona - nos seguintes termos: «...fui levada em parte onde me foram diante meus olhos apresentadas em coisas alheas todas as minhas angústias, e o meu sentido de ouvir não ficou sem sua parte de dor. Ali vi então, na piedade que houve de outrem, tamanha a devera ter de mim...»" ${ }^{92}$. Nesta citação não só se evidenciam as características fortemente «visuais» com que se concebia a própria narrativa literária, como o papel sentimental das imagens sugeridas ou concretizadas: excitar a piedade no receptor, fosse ele leitor, ouvinte ou espectador... Tal era, também, o papel da imagem devocional - fosse ela mais icónica ou mais narrativa: despertar e servir de veículo à ma-

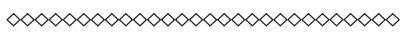

90 Sobre a figura do Mestre de Flémalle, ou Robert Campin, ver o recente ponto da situação em Susan Foister e Susie Nash (eds.), Robert Campin. New Directions in Scholarship, Londres, National Gallery/Brepols, 1996.

91 Citado por Lew Andrews, Story and Space..., cit., p. 29.

92 Bernardim Ribeiro, Menina e Moça de Bernardim Ribeiro, Lisboa: PEA, 1984, pp.56-57. 
nifestação de sentimentos de purificação espiritual e de resgate individual, na procura da Salvação, meta desesperadamente perseguida por uma sociedade fortemente mercantilizada, em curso de transformação ao nível da economia, da mentalidade e do gosto.

É possível acompanhar a generalização, por toda a Europa e em Portugal, da noção de estória (que julgamos derivada da assimilação do conceito albertiano de istoria ou, no mínimo, do termo habitualmente usado, na época, por oficiais e comitentes erigido à categoria de conceito da nóvel teoria da pintura pelo humanista italiano) no léxico utilizado nos contratos. No caso das fontes portuguesas, estória substitui o termo envocações, mais comum no século XV, num claro indício dos variados graus de assimilação pelas elites comitentes (sobretudo as eclesiásticas, mas também as laicas, desde as figuras ligadas à corte até à nobreza e aos mercadores ricos) do pendor narrativo (ou misto) prevalecente nas tendências artísticas correntes na Europa de então.

O desejo de aumentar o potencial narrativo da imagem não se manifestou, apenas, entre nós, na encomenda, sobretudo a partir de 1500, de monumentais máquinas retabulares para as principais sés catedrais e para algumas igrejas conventuais, ilustrando diferentes modelos de composição e diversos padrões de narratividade, mas também em estratégias de amplificação narrativa dentro de cada quadro, mobilizando amiúde os fundos para a colocação de episódios antecedentes, sequentes ou complementares dos que ocupam o primeiro plano, numa ilustração do princípio da narrativa contínua que o Renascimento fez renascer, como demonstrou Lew Andrews ${ }^{93}$.

Encontramos, por exemplo, variadas estratégias de «amplificação narrativa» em três composições do segundo quartel do século XVI que podemos ver no Museu Nacional de Arte Antiga: numa Criação de Adão, do círculo dos chamados Mestres de Ferreirim (na verdade, próxima da «maneira» de Garcia Fernandes) o fundo é ocupado com o episódio imediatamente sequente da Criação de Eva; já na belíssima Apresentação no Templo, de 1538, atribuída, com segurança, a Garcia Fernandes, o fundo é ocupado com a Circuncisão, episódio que, por vezes, é confundido com o do primeiro plano, revelando, neste caso, a subtileza da encomenda; finalmente, um outro quadro de Garcia Fernandes, que, ao que tudo indica, se «especializou» neste tipo de estratégia de continuidade narrativa, apresenta-nos dois Milagres de Santo António, o da Pregação aos Peixes, em primeiro plano, e o «milagre eucarístico da burra» no fundo.

O aumento e alargamento do campo visual na pintura (o espaço plástico teatral do Renascimento, tal como foi definido por Francastel) possibilitou, assim, um enorme desenvolvimento do potencial narrativo da imagem (ou, se quisermos, da istoria), em contraste, todavia, com a tendência para a progressiva consagração retórica das unidades de espaço, de acção e de tempo que a poética humanista parecia favorecer, por influência da recuperação da poética de Horácio, e iria, de resto, impor, a pouco e pouco, na literatura coeva, até atingir o seu ponto culminante na estética maneirista e barroca.

Para terminar esta abordagem dos problemas da narratividade pictural pós-me-

$\alpha<\infty<\infty<\infty<\infty<\infty<\infty<\infty<\infty<\infty<\infty<\infty$

93 Cf. Lew Andrews, Story and Space..., cit.. 
dieval, vamos tentar caracterizar as diferentes etapas ou categorias de espaço-tempo figurativo consoante os períodos histórico-artísticos considerados. No Renascimento, encontramos, como vimos, uma acentuada preocupação com a descrição de uma ação. Seja através de uma sucessão de episódios, tratados no interior de uma composição, aproveitando os seus diferentes planos, em narrativa contínua, ou num conjunto de composições de sequência linear, em sucessivos andares, ou, ainda, numa concentração de referências descritivas sabiamente distribuídas pela composição, o que caracteriza o espaço-tempo figurativo é, precisamente, essa preocupação com a descrição de uma ou várias ações, como se a composição pictural tirasse a sua identidade própria desses tempos somados ou concentrados, mas sempre «história», ou seja, sucessão de ações, tal como se encontra na cronística e na novelística coevas.

Acompanhando a recuperação das teorias poéticas da Antiguidade - que, a partir de uma releitura «radical» de Aristóteles e de Horácio, conduziria, na estética maneirista e barroca, à imposição da teoria das três unidades, de ação, de lugar e de tempo ${ }^{94}$ - assistiu-se, a partir dos primeiros decénios de Quinhentos, a uma tendência para a concentração no espaço-tempo figurativo, contrariando a dispersão atomística de «eventos»e ações, primeiro com a eleição do acontecimento paradigmático, depois com a escolha do «momento» revelador da essência do episódio. Neste último caso, estamos já no espaço-tempo figurativo do Maneirismo, que não está principalmente preocupado com a história que se conta mas com a lição moral que dela pode ser extraída, mediante por vezes complexas alegorias (como vemos nos elaborados retratos de Hans Holbein).

Um exemplo precoce é-nos dado pela obra pictórica de Miguel Ângelo na Capela Sistina, nomeadamente nos frescos da abóbada, em que, por entre elementos escultóricos «simulados» (medalhões e relevos) e monumentais «esculturas» em trompe l'oeil (os ignudi, as Sibilas e os Profetas), aparecem «quadros narrativos» dos grandes «momentos» da Criação. No central, dedicado à Criação de Adão, o que o genial pintor representou foi o «momento» em que Deus infundiu o espírito no primeiro Homem. Mas, alguns anos antes, no David, Miguel Ângelo, ao contrário de toda a tradição anterior, que optara por figurar o herói bíblico após a consumação do seu duelo com Golias, preferiu representar o «momento» da tomada de decisão, por inspiração divina, que iria mudar a sua própria vida e a do seu Povo, antes da vitória sobre o gigante ${ }^{95}$.

Finalmente, nos finais de Quinhentos, na obra do Caravaggio, vamos surpreender a emergência de um novo espaço-tempo figurativo assente na categoria de «instante», que vai marcar toda a estética barroca. Da vasta obra de Rubens (o grande revolucionador da iconografia católica) à perturbante escultura de Bernini (por exemplo, o seu Da-

$\infty<\infty<\infty<\infty<\infty<\infty<\infty<\infty<\infty<\infty<\infty<$

94 Cf. Renselaar W. Lee, Ut Pictura Poesis. La teoría humanística de la pintura, trad. cast., Madrid: Cátedra, 1982, especialmente pp. 13-22 e 123-129.

95 Não é esta a interpretação que a historiografia italiana e internacional habitualmente dá à obra, quando o faz, preferindo caracterizá-la como uma «meditação» sobre o sucedido. Tal visão parece-me desmentida pelo olhar fixo de David, que observa o seu gigantesco e atemorizador opositor no momento em que tem a inspiração divina que lhe vai permitir vencê-lo. Seja como for, não estamos diante de uma obra descritiva de uma ação mas evocativa de um estado de espírito do herói. 
vid, surpreendido no instante em que lança a pedra), dos pequenos quadros de Vermeer, sublimação das convenções do género, à pintura «engenhosa» de Velázquez, é sempre na captura de um «instante» que se resolve a composição.

\section{Epílogo}

O século XX levou muito tempo não só a entender como a aceitar o conceito albertiano de istoria, confundindo-o, como atrás referimos, com a tradição académica da «pintura de história», no que manifestava uma acentuada distância senão mesmo frontal recusa face a qualquer tipo de narrativa que não fosse a dos próprios processos de execução artística. De resto, o Renascimento foi visto pelas sucessivas gerações do Modernismo como o início da libertação da Arte do paradigma da «representação» do transcendente em favor de uma progressiva afirmação «pura» dos valores estéticos e artísticos.

Só por intermédio dos estudos semiológicos sobre o sistema visual do quattrocento, na esteira das obras pioneiras de Panofsky, Francastel e Baxandall, e já sob um paradigma pós-moderno de inter e transdisciplinaridade, foi reaberto o dossiê do problema da «representação», doravante apeada do seu papel «fantasmagórico» (para a arte dos diversos avatares do modernismo, entenda-se) e assumida como «interpretação», assim como foram reabilitados tanto o modelo «icónico» como o modelo narrativo do Renascimento, em resposta, finalmente, às necessidades de recuperação do «sublime» sentidas crescentemente pela sociedade pós-industrial e pós-moderna nas últimas décadas.

O regresso à «narratividade» e ao «sublime» apresenta-se, hoje, como uma poderosa interiorização de um novo espaço-tempo figurativo na arte contemporânea, que, por sinal, vinha sendo dominada pela emergência de um «novo naturalismo» do objet trouvé. Por outro, os criadores vêem-se confrontados, de um lado, com a emergência das novas tecnologias da comunicação, em que, depois da fotografia, do cinema e do vídeo, se «navega» nas novas «auto-estradas» da informação por intermédio de sucessivas «janelas» (Windows) e, sobretudo, se abre um novo e espantoso continente à criatividade, $o$ da realidade virtual, e, por outro, com os movimentos aparentemente contraditórios da globalização e da afirmação das «diferenças» locais e regionais.

Finalmente, no plano da relação do artista com o seu público, dir-se-ia que se iniciou um processo inverso ao da crescente individualização e libertação do processo criador que caracterizou o Renascimento: o papel do actual «curador» todo-poderoso na concepção de exposições, na definição do conceito, assim como na escolha dos artistas e das temáticas que estes deverão tratar, traz à lembrança a acção dos mecenas e patronos e até de alguns humanistas na definição dos programas iconográficos que presidiam às grandes criações. 